УДК 343.3/.7

DOI https://doi.org/10.32837/yuv.v0i2.2176

\title{
А. Щербіна,
}

аспірант кафедри кримінального права та кримінології

факультету № 1

Донецького державного університету внутрішніх справ

\section{МІЖНАРОДНІ СТАНДАРТИ КРИМІНАЛЬНО-ПРАВОВОЇ ОХОРОНИ НОРМАЛЬНОЇ РОБОТИ АВТОМАТИЗОВАНОЇ СИСТЕМИ ДОКУМЕНТООБІГУ СУДУ}

\begin{abstract}
Удосконалення національної нормативно-правової бази важко уявити без запозичення позитивного міжнародного та зарубіжного досвіду. Міжнародна правова спільнота регулярно працює над низкою проблемних питань, вирішення яких позитивним чином вплине на більшість законодавств. Варто звернути увагу на те, що, незважаючи на автентичність кожного окремого кримінального законодавства, більшість форм суспільно небезпечної діяльності є дуже схожими. Це стосується і кримінальних правопорушень проти правосуддя загалом та незаконного втручання в роботу автоматизованої системи документообігу суду зокрема. Нині в усьому світі вчені намагаються розробити засоби та заходи, які сприятимуть протидіі протиправного впливу на роботу електронно-обчислювальних машин з метою захисту безпеки інформації. Не $є$ винятком і автоматизовані системи, котрі зберігають дані, які належать суду. Саме тому низкою міжнародних нормативно-правових актів було сформульовано сукупність основних принципів, на яких має будуватись кримінально-правова охорона такого роду даних.

Отже, 12 грудня 2003 р. була прийнята Декларація $\mathrm{OOH}$ «Побудова інформаційного суспільства - глобальна задача в новому тисячолітті». Декларацією, зокрема, проголошено такі важливі принципи побудови
\end{abstract}

інформаційного суспільства: 1) верховенство права поряд зі сприятливою, прозорою, такою, що сприяє конкуренції, заснованою на принципі технологічної нейтральності і передбачуваною політичною i регламентарною базою, враховує національні особливості, необхідні для створення орієнтованого на інтереси людей інформаційного суспільства; 2) використання і розгортання IKT повинні бути спрямовані на створення переваг у всіх аспектах нашого повсякденного життя; 3) додатки на базі IKT потенційно важливі для діяльності органів державного управління i наданих ними послуг [1]. Основні рекомендаціï щодо впровадження електронної демократії викладені у Рекомендації CM/Rec (2009) 1 KM PE державам-членам від 18 лютого 2009 р. [2]. Натепер світова спільнота активно працює над створенням та/або удосконаленням електронного суду. При цьому жодний нормативно-правовий акт сучасної України не має вичерпної дефініції такого феномена, що наштовхує на думку про те, що законодавець сам неповною мірою розуміє загальні особливості електронного суду та порядку їх запровадження в національну правову систему. На наш погляд, під електронним судом необхідно розуміти інформаційно-аналітичну підсистему, завдання якої полягає у забезпеченні всебічної технологізаиії процесу судового 
документообігу та діловодства, а також налагодження алгоритму взаємодіі з учасниками судового процесу з метою дотримання їхніх прав та законних інтересів.

У цьому ж документі міститься дефініція електронного правосуддя: «використання IKT (інформаційних та комунікаційних технологій) у реалізації правосуддя всіма зацікавленими сторонами в юридичній сфері 3 метою підвищення ефективності та якості державних служб, зокрема для приватних осіб та підприємств. Це включає у себе електронний зв'язок і обмін даними, а також доступ до судової інформації (Р. 38). Рекомендація $\operatorname{Rec}(2001) 3 \mathrm{KM}$ P€ державам-членам «Щодо надання громадянам судових та інших юридичних послуг 3 використанням новітніх технологій» вказує на необхідність забезпечення можливості: 1) відкриття провадження за допомогою електронних засобів; 2) здійснення подальших процесуальних дій у рамках провадження у середовищі електронного документообігу; 3) отримання відомостей про хід справи шляхом одержання доступу до судової інформаційної системи; 4) одержання інформації про результати провадження в електронній формі (п. 3) [3]. Нідерландський експерт Дорі Рейлінг зазначає чотири рівні електронної взаємодії між громадянами та владою, що розроблені в ЄC: перший рівень - онлайнова інформація про загальнодоступні послуги; другий рівень - одностороння взаємодія: завантаження форм із сайтів; третій рівень - двостороння взаємодія: обробка форм (у тому числі аутентифікація), процесуальні дії у цифровій формі; четвертий рівень - транзакція: робота зі справою, прийняття та оголошення рішення, оплата [4, с. 4]. Варто звернути увагу на те, що фактично електронний суд являє собою автоматизовану систему документообігу суду, в іiі «чистому» вигляді.
Одним з головних підсумків сьомого Конгресу Організації Об'єднаних Націй 3 профілактики злочинності i поводження 3 правопорушниками, що проходив у Мілані (Італія) з 26 серпня по 6 вересня 1985 року, $€$ прийняття Основних принципів незалежності судових органів. У своїй резолюції про Основні принципи, яка наводиться нижче, Конгрес рекомендував їх для використання в межах національної, регіональної та міжрегіональної діяльності і закликав Комітет з профілактики злочинності та боротьби з нею розглянути питання про ефективне першочергове їх впровадження. Конгрес звернувся до Генерального секретаря Організації Об’єднаних Націй вжити належних заходів для забезпечення максимально широкого поширення Основних принципів і підготувати доповідь про їх здійснення. У своїй резолюціі 40/146 від 13 грудня 1985 року Генеральна Асамблея вітала Основні принципи і запропонувала урядам дотримуватися ї та брати до уваги в межах свого національного законодавства і практики. За рекомендацією Комітету профілактики злочинності та боротьби з нею Економічна i Соціальна Рада запропонувала державам-членам кожні п'ять років, починаючи з 1988 року, інформувати Генерального секретаря про результати, досягнуті у здійсненні Основних принципів (резолюція 1986/10 від 21 травня 1986 року) [5, с. 19]. Такий підхід було запроваджено 3 метою своєчасного реагування на ймовірні проблеми, які можуть виникнути під час реалізації системи електронного суду.

Сюди входила б інформація, що стосувалася іх поширення, включення в національне законодавство проблем, що виникають у ході діяльності 3 ї здійснення на національному рівні, а також допомога, яка, можливо, буде потрібна з боку міжнародної спільноти. Генеральна Асамблея вітала цю рекомендацію

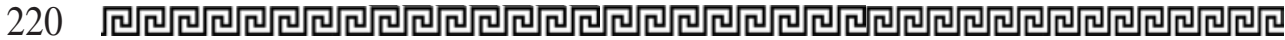


Ради у своїй резолюції 41/149 від 4 грудня 1986 року про права людини у разі здійснення правосуддя. В Основних принципах підкреслюється, що незалежність судових органів гарантується державою i закріплюється в конституції або законах країни. Правосуддя вимагає, щоб кожен мав право на справедливий i публічний розгляд у компетентному, незалежному та об’єктивному суді відповідно до принципів, проголошених у Загальній декларації прав людини (стаття 10), Міжнародному пакті про громадянські й політичні права (стаття 14) та інших документах Організації Об'єднаних Націй. Для здійснення цього права необхідно мати незалежний судовий орган [5, с. 20]. Вказана пропозиція здається досить доречною, оскільки дає можливість зробити судовий процес максимально прозорим та відкритим. Більше того, такий підхід дозволить знизити корупційні ризики та загальну кількість такого роду кримінальних правопорушень (у т. ч. у сфері правосуддя).

3 огляду на те, що у Статуті Організації Об'єднаних Націй народи світу заявляють, зокрема, про свою рішучість створити умови, за яких можна дотримуватися справедливості, щоб забезпечити міжнародне співробітництво в заохоченні і розвитку поваги до прав людини і основних свобод без будь-якої різниці; з урахуванням того, що в Загальній декларації прав людини втілені, зокрема, принципи рівності перед законом, презумпціï невинності і права на справедливий i відкритий судовий розгляд компетентним, незалежним i неупередженим судом, заснованим відповідно до закону; $з$ урахуванням того, що Міжнародний пакт про економічні, соціальні і культурні права і Міжнародний пакт про громадянські і політичні права гарантують також право бути судженим без невиправданої затримки; з урахуванням того, що все ще часто існує невідповідність між уявленням про ці принципи і фактичним становищем; 3 урахуванням того, що в організації і відправленні правосуддя в кожній країні слід керуватися цими принципами і що треба докладати зусиль для повного втілення їх у життя; з урахуванням того, що норми, які стосуються здійснення функцій судді, мають бути націлені на те, щоб забезпечувати суддів можливістю діяти відповідно до цих принципів; з урахуванням того, що на суддів покладається обов'язок приймати остаточне рішення 3 питань життя і смерті, свободи, прав, обов'язків і власності громадян; з урахуванням того, що шостий Конгрес Організаціï Об’єднаних Націй з профілактики злочинності і поводження з правопорушниками у своїй резолюції просив Комітет з профілактики злочинності та боротьби 3 нею включити до першочергових завдань розробку керівних принципів, що стосуються незалежності суддів та відбору, професійної підготовки і статусу суддів та прокурорів; 3 урахуванням того, що в зв'язку з цим потрібно насамперед розглянути питання про роль судів у системі правосуддя і важливість їхнього відбору, підготовки й поведінки; урядам слід було б брати до уваги і шанувати в межах свого національного законодавства і практики, доводити до відома суддів, адвокатів, працівників виконавчих і законодавчих органів і широкої громадськості основні принципи, сформульовані для того, щоб допомогти державам-членам у вирішенні завдань забезпечення і зміцнення незалежності судових органів [5, с. 21]. Саме ці завдання було покладено в основу створення автоматизованих систем документообігу як одного із гарантів удосконалення взаємодіі судових органів між собою, а також іншими організаціями та установами, громадянами та учасниками судового процесу.

Принципи сформульовані головним чином для професійних суддів, однак у разі необхідності вони рів- 
ною мірою можуть застосовуватись і до непрофесійних суддів, якщо такі є. Незалежність судових органів гарантується державою i закріплюється в конституції або законах країни. Усі державні та інші установи зобов'язані шанувати незалежність судових органів і дотримуватися iii. Судові органи вирішують передані їм справи безсторонньо, на основі фактів і відповідно до закону, без будь-яких обмежень, неправомірного впливу, спонуки, тиску, погроз або втручання, прямого чи непрямого, з будь-якого боку і з будь-яких причин. Судові органи мають компетенцію стосовно всіх питань судового характеру i виняткове право вирішувати, чи входить передана їм справа до їхньої встановленої законом компетенції. Не повинно мати місце неправомірне чи несанкціоноване втручання в процес правосуддя, а судові рішення, винесені суддями, не підлягають перегляду. Цей принцип не перешкоджає здійснюваному відповідно до закону судовому перегляду чи пом'якшенню вироків, винесених судовими органами. Кожна людина має право на судовий розгляд у звичайних судах або трибуналах, які застосовують встановлені юридичні процедури. Не повинні утворюватися трибунали, що не застосовують встановлені належним чином юридичні процедури, з метою підміни компетенції звичайних судів або судових органів. Принцип незалежності судових органів дає судовим органам право і вимагає від них забезпечення справедливого ведення судового розгляду i дотримання прав сторін. Кожна держава-член повинна надавати відповідні засоби, які давали б змогу судовим органам належним чином виконувати свої функції [5, с. 22]. У зазначеному контексті найбільш цінною є думка міжнародної спільноти про те, що не повинно мати місця неправомірне чи несанкціоноване втручання в процес правосуддя, а судові рішення, винесені суддями, не підлягають перегляду. Саме це правило вказує на прозорість та безпечність судового процесу, на об'єктивне та неупереджене правосуддя.

$\mathrm{y}$ цьому Висновку йдеться про застосування сучасних інформаційно-комунікаційних технологій (IT) у судах. Цей Висновок концентрує свою увагу на можливостях, які пропонує IT у розрізі взаємодії та впливу на судову владу та судочинство. Особливо це стосується таких проблем, як доступ до правосуддя, верховенство права, незалежність суддів та судової влади, функціонування судів, дотримання прав та виконання обов'язків учасників судочинства. Висновок не стосується технічних аспектів функціонування IT. IT повинні бути інструментом або засобом покращення адміністрування судочинства, полегшувати доступ користувачів до судів та укріплювати гарантії, встановлені статтею 6 Європейської Конвенції з прав людини (ЄКПЛ ECHR): доступ до правосуддя, неупередженість, незалежність судді, справедливість та розумні терміни розгляду справи [5, с. 287]. Таким чином, комп'ютеризація дає суддям можливість своєчасно вносити дані, які надалі можуть бути використані як доказ об'єктивного рішення у кожній окремій справі.

Впровадження IT у судах Європи не повинне шкодити авторитету та кадровому забезпеченню судової системи. Якщо судочинство буде сприйматися користувачами як суто технічний процес без його реальної та фундаментальної функції, здійснення правосуддя може стати повністю автоматизованим без участі людського фактора. Судочинство насамперед має містити людський фактор, оскільки тут ідеться про реальних людей та про вирішення їхніх спорів. Найвагоміше значення людський фактор має в оцінці поведінки сторін та їх свідків у судовому засіданні, що і становить складник роботи судді [5, с. 288]. Насправді,

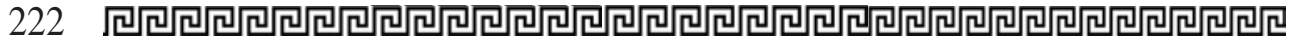


комп'ютеризація - це лише один зі шляхів спрощення ведення документації та підтримання внутрішніх та зовнішніх зв'язків. Безпосередньо правосуддя - це складний процес, котрий полягає у поєднанні об'єктивних та суб'єктивних можливостей судді сприйняти всі обставини справи з метою винесення єдино правильного та справедливого рішення.

Велика хартія покладає на суддів відповідальність за доступ до швидкого, ефективного врегулювання спорів. Судді мають чітко відзначати як переваги, так і недоліки IT, ураховувати та не допускати будь-яких порушень у здійсненні правосуддя. IT не повинні обмежувати процесуальні права сторін. Судді повинні усвідомлювати можливість такої загрози, оскільки саме вони відповідальні за дотримання та захист прав сторін. Судді повинні брати участь в оцінці впливу IT, особливо якщо вимагається або дозволяється застосування електронних засобів у діловодстві та/або судовому процесі. Не всі особи мають доступ до IT. 3 огляду на сучасну ситуацію, не потрібно нехтувати традиційними засобами доступу до інформації. Довідкові стенди та інші форми допомоги, що надаються у судах, не повинні зникнути з огляду на те, що IT зробили судочинство доступним для усіх. Ці заходи - невідкладна турбота про соціально незахищені та вразливі верстви населення. Використання IT не повинне обмежити процесуальні права та гарантії тих, хто не має доступу до сучасних технологій; держави мають гарантувати, що їм надають відповідну допомогу в цій сфері. 3 огляду на ту важливу роль, яку IT відіграють нині у здійсненні судочинства, особливо важливим є гарантія того, що використання IT навіть на короткі періоди не буде уповільнювати роботу суду щодо вирішення спорів та здійснення інших процесуальних дій. Щоб уникнути будь-якого негативного впливу на діяльність суду, мають існувати альтернативні рішення, якщо IT виходять 3 ладу, з'являються технічні несправності тощо [5, с. 289]. Всі ці особливості нині покладені в основу розробки електронного суду в Україні. Однак, на жаль, наша країна досі не розробила певні стандарти, котрі забезпечували би безпеку та ефективність такого роду підсистеми.

На пильну увагу заслуговує оцінка законопроєктів стосовно впровадження IT та кола проблем, пов'язаних з їнім використанням. КРЕС наголошує на тому, що нове законодавство з цих питань має набрати чинності тільки після того, як системи IT будуть адаптовані до нових вимог, а кадровий персонал суду буде навчений відповідним чином. Використання IT у судочинстві - це особливо важлива тема у сфері міжнародної та європейської співпраці. IT можуть використовуватися у сфері обміну необхідними відомостями, запитів до іноземних судів, повідомлень держав-членів щодо судових документів, а також для міжнародного дослідження доказів (наприклад, шляхом застосування відеоконференцзв'язку), КРЕС рекомендує державам розглянути можливість надання взаємного доступу до національних IT систем, створення таких систем, сумісних одна з одною. Це зможе стати гарантією, що IT здатні підняти на якісніший рівень співпрацю суддів у різних країнах та не створювати при цьому будь-яких перепон. КРЕС прихильно ставиться до рішень, що були прийняті деякими державами на виконання інструкцій Європейського Союзу, які дозволяють відкривати провадження у цивільних справах у спорах між громадянами різних держав в електронному вигляді, а також використовувати відеоконференцзв'язок у рамках міжнародної співпраці [5, с. 290]. До речі, комп'ютеризація може також позитивно впливати на міжнародні зв'язки між судами та обмін досвідом проведення судового розслідування. 
Використання IT покращує доступ до судочинства, а також підвищує його ефективність та прозорість. 3 іншого боку, це потребує значних фінансових інвестицій. У рекомендації 289 KРЕС ідеться про те, що доступ до судочинства має покращуватися, в тому числі і за рахунок використання IT, тому держави повинні проявляти відповідну фінансову підтримку. Бази даних та інформація, яка міститься в реєстраційних журналах, матеріалах справ, підготовчих документах та проєктах, судових рішеннях, статистичних даних стосовно оцінки діяльності суддів та суду загалом, повинна захищатися на відповідних рівнях безпеки. В межах суду доступ окремих працівників повинен бути обмеженим відповідно до функціональних обов'язків. Беручи до уваги природу спорів, що розглядаються у судах, онлайн-доступ до судових рішень може порушити особисті права громадян та становити загрозу інтересам підприємств. Отже, суди та судові органи повинні забезпечити належний захист бази даних, i це має бути закріплене на законодавчому рівні. КРЕС заохочує розвиток IT як інструмента покращення спілкування між судами та 3MI, надаючи ЗMI більш легкий доступ до судових рішень, а також до розкладу призначених судових засідань [5, с. 290]. Сфера IT - сукупність потужних можливостей удосконалення майже всіх сфер життедіяльності суспільства. Комп'ютеризація значно спрощує доступ до необхідних даних та інформації. При цьому активний розвиток шахрайств, які вчиняються з використанням комп'ютерної техніки, хакерські атаки та інші кіберправопорушення свідчать про не досить повноцінно організований рівень захисту інформаціiі. У зарубіжних країнах це питання стоїть не так гостро, у зв'язку із чим більшість європейських держав вдало інтегрували у свою нормативно-правову базу рекомендації міжнародної спільноти в частині розвитку автоматизованих систем у роботі судів.
Повна, достовірна та своєчасна інформація 3 питань здійснення судочинства $є$ основним аспектом, що гарантує доступ до правосуддя, як це зазначено у статті 6 ЄКПЛ. Судді мають переконатися, що кожна особа, яка бере участь у судовому процесі, має доступ до достовірної інформації. Така інформація повинна містити дані або вимоги, дотримання яких необхідне у судовому процесі. Зазначені заходи потрібні для забезпечення рівності сторін у засобах захисту своїх прав. У будь-якому разі судова система не може існувати окремо від користувачів іï послуг, а розвиток IT не звільняє суди від відповідальності. IT створює нові можливості для судів у наданні користувачам судових послуг загальної інформації стосовно судової системи, іiі діяльності, прецедентного права, судових витрат та ризиків судового процесу, альтернативних методів вирішення спорів тощо. КРЄС рекомендує судовій системі використовувати Інтернет та інші нові технології у повному обсязі 3 метою надання широкій публіці тих елементів, які відповідно до Висновку № 6 (параграф 12 та наступні) повинні бути поширені серед громадськості [5, с. 291]. Нині йдеться про інформацію, котра може сприйматись користувачем як прецедентна та бути використана як зразок можливого вирішення його власної справи. Також ідея «відкритого» судового процесу дозволяє особі знайомитись 3 матеріалами інших учасників як 3 метою отримання певного досвіду, так і для набуття юридичної освіти, збирання доказової інформації тощо.

IT $є$ потужним інструментом у підтримці ролі судів. ІТ також можуть покращити процедуру ознайомлення зацікавлених осіб з інформацією щодо судочинства загалом. 3 цією метою КРЄС рекомендує судам запровадити електронні довідкові служби. IT дозволяють учасникам ініціювати процес в електронному вигляді (електронний документообіг). КРЕС підтри-

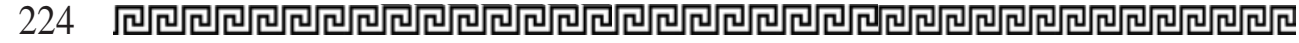


мує подальший розвиток цієї практики. КРЄС вважає, що судова влада має створити прецедентне право, принаймні, опубліковувати резонансні рішення, доступні в Інтернеті: а) на безоплатній основі; б) в легкодоступній формі та в) із урахуванням захисту особистих даних. КРЕС прихильно ставиться до ініціативи ввести міжнародні ідентифікатори прецедентного права (як ідентифікатор прецедентного права Європейського Союзу ECLI203), які покращують доступ до іноземного прецедентного права [5, с. 292]. Насправді, говорити про популяризацію професії судді нині не доводиться. Суддівство протягом століть вважалось досить престижною та складною професією, котра вимагає від людини максимальної об'єктивності та концентрації. Однак знайомство з такого роду професією має відбуватись «зсередини», через ті складні випадки, які перебувають на розгляді. В цьому контексті йдеться насамперед про прецедент. Україна не $є$ прихильницею цього феномена, що має як позитивні, так i негативні сторони. Якщо говорити про позитивні, то тут єдиним є те, що неправильний та занадто жорсткий, іноді суб'єктивний підхід до справи може несправедливо інтегруватись у наступні аналогічні випадки. Наша країна, на жаль, не є взірцем досконалого правосуддя, що підтверджується низкою випадків прийняття помилкових рішень та засудження невинних осіб. Що стосується негативних сторін ігнорування нашою країною прецеденту - це втрата шансу прискорити винесення рішень.

IT пропонує можливості більш ефективного, прозорого та суттєвого розгляду справ. Комп'ютеризація здатна покращити якість роботи судді, наприклад, за допомогою бази даних 3 посиланнями на судові рішення, законодавчу базу, наукові праці з правових питань, коментарі до постановлених рішень, а також інші форми обміну знань між суддями. Довершені та найповніші бази даних для обміну інформацією у зазначеній сфері мають бути доступними на безоплатній основі, з огляду на те, що судді могли перевірити всі можливі джерела інформації з правових питань, які доступні іншим учасникам процесу (адвокатам, експертам та ін.). Така правова допомога має сприйматися як допоміжний засіб у судовому процесі та має покращувати процес прийняття рішень суддею, а не обмежувати його. Звернення до послуг IT покрашує документообіг. Сторони та їхні представники можуть отримати доступ до інформації по справах, в яких вони є зацікавленими особами. Таким чином, вони можуть прослідити за рухом своєї справи, отримавши доступ до електронної версії історії руху справи [5, с. 293]. Отже, автоматизація документообігу суду спрощує не тільки роботу суду, а і надає можливість громадянам спостерігати за рухом своїх справ. Однак ця медаль має дві сторони. Негативною є ймовірне прагнення особи незаконним чином змінити хід розгляду шляхом внесення неправдивої інформації, що провокуватиме виникнення умислу на незаконне втручання в роботу автоматизованої системи документообігу суду.

Відеоконференцзв'язок може полегшити проведення судових засідань $з$ точки зору покращення безпеки та відібрання свідчень у свідків та експертів. Особливу уваги необхідно приділити тому, щоб конференцзв'язок та відібрання свідчень у такий спосіб не порушувало гарантоване право осіб на захист. Роль IT має бути обмеженою та проявлятися у заміщенні та спрощенні процесуальних дій, які ведуть до прийняття індивідуального рішення. IT не можуть замінити функції судді щодо заслуховування та виваження фактичних доказів у справі, щодо визначення відповідного законодавства та прийняття рішення без будьяких обмежень, окрім зазначених 
у законі. IT мають використовуватися для посилення незалежності суддів на кожному етапі судового процесу, а не загрожувати їи. Оскільки судді мають плекати неупередженість, індивідуальну та інституційну незалежність, необхідно залучати ї до процесу прийняття рішень стосовно використання IT. Доступ до інформаціï із застосуванням IT може сприяти розширенню автономіі суддів у виконанні покладених на них завдань. Залежність від технологій та тих осіб, які ними управляють, може поставити під загрозу процес здійснення судочинства. Технології мають бути адаптовані до потреб судочинства та всіх аспектів роботи судді. Судді не повинні, виходячи з одних лише мотивів покращення ефективності, підпорядковуватися функціонуванню технологій та тим, хто ними управляє. Технології мають бути адаптовані до різних типів справ та рівнів складності. КРЄС вважає, що інструкції, шаблони або інші пропозиції стосовно змісту судових рішень, які рекомендуються суддям для використання, не повинні розроблятися будь-якими іншими органами влади, які керують процесом використання IT у судочинстві; окрім випадків, коли структура такого керівництва буде гнучкою та зможе адаптуватися до прецедентного права чи практики [5, с. 294]. У сучасних умовах відеоконференцзв'язок допомагає суддям ефективно виконувати свої повноваження на відстані, що є дуже актуальним у світлі пандеміï COVID-19. Також це $є$ цінним, якщо учасники судового процесу (наприклад, свідок) перебувають в іншому місті або країні та не можуть своєчасно прибути на засідання.

Абсолютно необхідним $є$ діалог між розробниками технологій та особами, які несуть відповідальність за здійснення судочинства. Управління IT має належати до компетенції Ради судової влади або іншому відповідному незалежному органу. Незалежно від того, який орган відповідає за управління IT, має існувати гарантія, що судді в повному обсязі беруть участь у процесі прийняття рішень стосовно використання IT. Судді повинні мати гнучкі повноваження стосовно розгляду справ та ведення документообігу за допомогою апарату суду. Питання здійснення документообігу не повинні обмежувати цю гнучкість. Судді та апарат суду мають право та зобов'язані пройти первинний курс навчання використання IT, а також наступні курси підвищення кваліфікації. IT може стати важливим інструментом у посиленні прозорості та об'єктивності процесу розподілу і передачі судових справ суддям. Це може вплинути на оцінку суддів та судів. Однак дані, зібрані у системі IT, не повинні бути єдиним джерелом інформації в аналізі роботи окремого суду. Статичні дані також мають досліджуватися Радою судової влади або іншим відповідним незалежним органом. Управління та розвиток IT є своєрідним випробуванням для будь-якої організації. Для вищих органів керівництва судовою владою це являє собою нову проблему, яка вимагає великих зусиль. Управління, засноване на інформації, - це можливість розвинути встановлену незалежність [5, с. 295]. Натепер більша частина органів виконавчої та судової влади вже перейшли на електронну форму документообігу. Це зумовлене прагненням прискорити процедуру перевірки документів спеціальними комісіями, удосконалити процес листування та складання звітності. Електронний документообіг також дає можливість керівництву на відстані регулювати та контролювати процес виконання роботи працівниками. Введення такого роду автоматизованої системи дозволило зробити правосуддя більш доступним. Яскравим прикладом є Єдиний реєстр судових рішень. Однак з метою протидії незаконним діям із автоматизованими системами суду працівники суду, а також особи, 
уповноважені на роботу із такими системами, повинні проходити спеціальне навчання.

Засади фінансування розвитку IT мають відповідати значенню внеску IT у покращення роботи суду, якості правосуддя та рівня обслуговування громадян. Отже, висновки-рекомендації полягають у такому: а) KPЄC оцінює IT як засіб покращення здійснення судочинства; б) IT можуть полегшити доступ до правосуддя, покращити процес розгляду та руху справ, підвищити рівень судочинства; в) IT відіграють центральну роль у наданні інформації суддям, адвокатам та іншим зацікавленим особам у системі правосуддя, громадськості та 3MI; г) IT мають бути адаптовані до потреб суддів та інших користувачів системи, це в будьякому разі не повинне порушувати гарантії та процесуальні права, принцип неупередженості у разі розгляду справи; г) судді мають брати участь у прийнятті всіх рішень стосовно використання та розвитку IT у судовій системі; д) слід брати до уваги потреби тих осіб, які не в змозі використовувати засоби IT; е) судді мають бути уповноважені наполягти на особистій присутності зацікавлених сторін, на наданні друкованих документів та на усних засіданнях. IT не може заміняти повноваження судді стосовно вивчення та оцінки доказів. є) КРЄС заохочує використання IT 3 метою посилення ролі судової системи в дотриманні верховенства права в демократичних державах і IT не повинні втручатися в повноваження судді та підривати керівні принципи, зазначені у статті 6 ЄКПЛ [5, с. 296]. Розглянуті нами міжнародні документи дали можливість констатувати, що міжнародна правова спільнота віддає перевагу інформатизації судового процесу та створює умови, в яких вона може бути реалізована максимально безпечно. Саме у зв'язку із цим більшості країн, котрі запрова- джують такого роду системи, намагаються забезпечити їі ефективну кримінально-правову охорону.

Таким чином, міжнародними стандартами кримінально-правової охорони нормальної роботи автоматизованої системи документообігу суду є загальноприйняті, закріплені на законодавчому рівні та інтегровані в практику міннародного співтовариства норми кримінального права, котрі полягають у: 1) визнанні правосуддя одним із пріоритетних напрямів кримінально-правової охорони; 2) створенні умов, необхідних для здійснення прозорого, неупередженого та об'єктивного правосуддя; 3) усуненні потенційних корупційних загроз; 4) прагненні до всесвітньої технологізації та стандартизації судового процесу; 5) встановленні максимально ефективних заходів та засобів кримінально-правового впливу на осіб, які посягають на автоматизовані системи документообігу суду; 6) забезпеченні незалежності судді у відправленні правосуддя.

Складниками міжнародних стандартів є: 1) визначення поняття «автоматизована система документообігу суду» як сукупності комп'ютерних програм і відповідних програмно-апаратних комплексів, що входять до складу Єдиної судової інформаційної системи; 2) якнайкраще забезпечення інтересів не тільки працівників суду, a i всіх учасників судового процесу; 3) диференціація видів кримінально-правового впливу від максимально лояльного до допустимо репресивного та достатнього; 4) диференціація суб'єктів кримінального правопорушення 3 урахуванням об'єктивних та суб'єктивних обставин вчинення протиправного діяння.

У статmі автор розглядае міжнародні стандарти кримінально-правової охорони нормальної роботи автоматизованої системи документообігу суду. Вказується, що натепер світова спільнота 
активно працуюе над створенням та/або удосконаленням електронного суду. При цьому жодний нормативно-правовий акт сучасної України не має вичерпної дефініціі такого феномена, що наштовхуе на думку про те, щзо законодавець сам неповною мірою розуміє загальні особливості електронного суду та порядку їх запровадження в національну правову систему. Автор вважае, що під електронним судом необхідно розуміти інформаційно-аналітичну підсистему, завдання якої полягає у забезпеченні всебічної технологізації процесу судового документообігу та діловодства, а також налагодження алгоритму взаємодії з учасниками судового проиесу з метою дотримання їніх прав та законних інтересів. Розглянуті міжнародні документи дали можливість констатувати, що міжнародна правова спільнота віддає перевагу інформатизації судового процесу та створюе умови, в яких вона може бути реалізована максимально безпечно. Саме у зв'язку із ичим більшість країн, котрі запроваджують такого роду систему, намагаються забезпечити ї ефективну кримінально-правову охорону.

Підсумовується, щзо міннародними стандартами кримінально-правової охорони нормальної роботи автоматизованої системи документообігу суду $е$ загальноприйняті, закріплені на законодавчому рівні та інтегровані в практику міжнародного співтовариства норми кримінального права, котрі полягають $у$ : 1) визнанні правосуддя одним із пріоритетних напрямів кримінально-правової охорони; 2) створенні умов, необхідних для здійснення прозорого, неупередженого та об'єктивного правосуддя; 3) усуненні потенційних корупційних загроз; 4) прагненні до всесвітньої технологізащіі та стандартизації судового про- цесу; 5) встановленні максимально ефективних заходів та засобів кримінально-правового впливу на осіб, які посягають на автоматизовані системи документообігу суду.

Ключові слова: міжнародні стандарти, кримінально-правова охорона, автоматизована система документообігу суду, кримінальне правопорушення, IT, інформатизація, правосуддя.

Shcherbina A. International standards of criminal legal protection of normal work of the automated court document system

In the article the author considers the international standards of criminal law protection of normal work of the automated system of document circulation of court. It is indicated that today the world community is actively working to create and/or improve e-court. At the same time, no normative legal act of modern Ukraine has an exhaustive definition of such a phenomenon, which suggests that the legislator himself does not fully understand the general features of e-court and the procedure for their introduction into the national legal system. The author believes that the e-court should be understood as an information-analytical subsystem, the task of which is to ensure comprehensive technologization of the process of judicial document management and record keeping, as well as establishing an algorithm for interaction with litigants to comply with their rights and legitimate interests. The considered international documents provided an opportunity to state that the international legal community prefers informatization of the judicial process and creates conditions in which it can be implemented as safely as possible. That is why most countries that introduce such systems are trying to ensure its effective criminal protection. It is concluded 


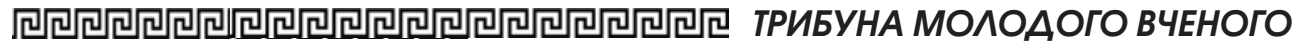

that the international standards of criminal law protection of the normal operation of the automated court document management system are generally accepted, enshrined in law and integrated into the practice of the international community norms of criminal law, which are: 1 ) recognition of justice as one of the priority areas of criminal justice; 2) creating the conditions necessary for the administration of transparent, impartial and objective justice; 3) elimination of potential corruption threats; 4) the desire for global technology and standardization of the judicial process; 5) establishing the most effective measures and means of criminal-legal influence on persons who encroach on the automated document management systems of the court.

Key words: international standards, criminal law protection, automated court document management system, criminal offense, IT, informatization, justice.

\section{Література}

1. Декларащія принщипів «Побудова інформаційного суспільства - глобальне завдання у новому тисячолітті». URL: http: / / zakon5.rada.gov.ua/laws / show/995_c57.

2. Рекомендаиї CM/Rec (2009) 1 Коміmету Міністрів Ради Європи державам-членам. URL: http: / / wwш.coe.int / / dgap / democracy / Activities / GGIS / CAHDE/2009/RecCM2009_1_and_ Accomp_Docs / Recommendation\% 20CM_ Rec(2009)1E_FINAL.asp\#TopOfPage.

3. Рекомендація Rec (2001) 3 Koмітету Міністрів Ради Європи державам-иленам "Щодо надання громадянам судових та інших юридичних послуг з використанням новітніх технологій». URL: http: / / sc.gov.ua/uploads / tinymce / files / 5.\% 2 $0 \%$ DO \% AO\% DO \% B $\%$ DO \% BA\% DO \% B $E \% \quad D 0 \%$ BC $\%$ DO $\%$ B $\%$ DO $\%$ BD $\%$ DO $\%$ $4 \%$ D0\% B0\% D1\% $86 \%$ D $1 \% 96 \%$ D $1 \% 8 F$ $\% 20$ Rec\% 20(2001)\% 203.pdf.

4. Рейлинг Д. Информационные технологии в судах Европь: мнения, практика u инновации. URL: http://home.hccnet. $\mathrm{nl} /$ a.d.reiling / html/Informatio.

5. Європейські та міжнародні стандарти у сфері судочинства, Київ, 2015. 708 c. 